РУДАКОВА Екатерина Константиновна - кандидат политических наук, доцент кафедры международных отношений и политологии, старший научный сотрудник Нижегородского государственного лингвистического университета им. Н.А. Добролюбова (603155, Россия, Нижний Новгород, ул. Минина, 31a; kafedra_mo_nglu@mail.ru)

\title{
МЕЖДУНАРОДНАЯ ДИСКУССИЯ ПО ПРОБЛЕМЕ ЗАЩИТЫ ПРАВ ЧЕЛОВЕКА ДО РОЖДЕНИЯ
}

Аннотация. Традиционно дискуссия вокруг прав человека носит правовой, юридический, философский характер, однако к вопросу о правах человека до рождения необходим междисциплинарный подход. $B$ данной статье представлены позиция ученых эмбриологов, биологов и генетиков по вопросу законодательного закрепления прав человека на жизнь и достоинство во внутриутробный период развития до рождения, а также последние данные фундаментальной науки о начале человеческой жизни и особенностях внутриутробной стадии развития человека. Обоснованы положения, что эмбрион во внутриутробный период обладает полнотой человеческого достоинства с момента зачатия, генетически не является телом или органом матери, нуждается в правовой гарантии безопасности и благоприятных условий для физиологического и психического развития.

Ключевые слова: права человека, права детей, аборт, эвтаназия, эмбриология, демография, безопасность

Сегодня идет активная дискуссия по вопросу о необходимости законодательного закрепления прав детей до рождения, т.е. права на жизнь и достойные условия развития человека во внутриутробный период. Это проблему многие связывают с попыткой снизить число абортов в мире, а также повысить рождаемость в развитых странах. Но основной причиной, по которой эту проблему стоит решать, является вопрос о нравственном облике будущего человечества, который в т.ч. измеряется уважительным и ответственным отношением ко всему живому, и прежде всего к человеческой жизни в ее непрерывности - от момента зарождения и до смерти.

Основная полемика развернулась вокруг вопроса, почему права человека гарантируются с момента физиологических родов и завершения внутриутробной стадии развития, а не с момента начала жизни, ведь в утробе матери человек уже является живым существом и проходит одну из стадий своего жизненного цикла.

Принято считать, что права гарантируются человеку «с рождения». Такое положение закреплено, например, в гл. 2 Конституции РФ1. Данное ограничение не соотносится с Европейской конвенцией по правам человека, в которой подобное ограничение не существует, формулировка конвенции следующая: «Право каждого лица на жизнь охраняется законом. Никто не может быть умышленно лишен жизни иначе как во исполнение смертного приговора, вынесенного судом за совершение преступления, в отношении которого законом предусмотрено такое наказание» ${ }^{2}$.

В полемике по легализации прав человека до рождения слышен голос юристов, философов, религиоведов, политиков, однако до сих пор консенсуса достичь не удалось - так и остался открытым вопрос: если каждому гаранти-

\footnotetext{
${ }^{1}$ Конституция РФ 1993 года. Гл. 2. Ст. 17. Права и свободы человека и гражданина. Доступ: http:// www.constitution.ru/10003000/10003000-4.htm (проверено 10.02.2020).

2 Конвенция о защите прав человека и основных свобод. - Европейская конвенция по правам человека. 1950. Доступ: https://www.echr.coe.int/Documents/Convention_RUS.pdf (проверено 30.04.2020).
} 
руется право на жизнь, что считать точкой отсчета. Очевидно, данный вопрос является предметом исследований не гуманитариев, а эмбриологов и генетиков, которые изучают человеческую жизнь с самых ранних стадий и могут дать более чем исчерпывающие ответы на все вопросы современной дискуссии - с какого момента начинается жизнь, является ли человек в утробе полноценным живым организмом, является ли эмбрион в утробной стадии развития человеком, обладает ли он эмоциями и чувствует ли он боль, наконец, обладает ли полнотой достоинства живого существа, нуждающегося в правовой защите.

Невозможно представить данные всех ученых, но основные тезисы, с которыми солидарны большинство ученых эмбриологов и генетиков, могут быть сгруппированы следующим образом.

1. Прерывание жсизни в утробе недопустимо. По мнению доктора биологических наук заслуженного профессора кафедры эмбриологии МГУ В.А. Голиченкова, прерывание жизни человека в утробе недопустимо. Сегодня необходимо защитить права детей во внутриутробный период, «поскольку сами они не могут заявить о своих правах, и если мы решим, что жизнь неприкосновенна, то все встанет на свои места, если же мы договоримся (и наука здесь не при чем), что это не человек, тогда юридически мы можем делать с ним все, что угодно. Чисто юридически, если смертная казнь разрешена, то убийство преступника не считается преступлением, а если запрещена, тогда это преступление. Для эмбриологии аборт - это убийство на любой стадии, за которое не предусмотрена уголовная ответственность. Жизнь неприкосновенна» [Голиченков 2015].

2. Внутриутробное развитие - это стадия непрерывной цепочки жмизни человека от зиготы до рождения. Отвечая на вопрос многолетнего спора сторонников и противников абортов о том, является ли зигота, эмбрион человеком, профессор кафедры эмбриологии МГУ В.А. Голиченков полагает, что «было бы прекрасно, если бы общество дозрело до понимания, что прерывание жизни человека недопустимо ни на какой стадии его развития, ни на стадии зиготы, ни на стадии бластоциды, ни позднего эмбриона, ни родившегося человека, ни глубокого старика, ни безнадежно больного». На каждой стадии, от рождения до смерти, человек меняет свою внешность, но остается все тем же живым существом, как зигота отличается от эмбриона, младенец от юноши, а юноша от старика - это все стадии одной непрерываемой цепочки жизни, каждая из которых является началом последующей [Голиченков 2015].

3. Жизнь начинается с зиготы. Для эмбриологии не существует дискуссии, с какого момента зарождается человеческая жизнь, это не вопрос для полемики. Сегодня существуют уже десятки псевдонаучных теорий о том, что является точкой отсчета начала человеческой жизни. Кто-то считает, что человек начинается с момента появления сердечной деятельности, нервной системы, первых толчков, первого вздоха, осознания себя, освоения речи или даже получения паспорта, - «все эти точки отсчета не продиктованы научными данными, хотя, казалось бы, именно с учеными нужно считаться в вопросе о том, когда зарождается человеческая жизнь».

Генетик, исследователь в области биоэтики, советник по правам ребенка доктор Мария дел Пилар Кальва Меркадо в своей публикации «Начало жизни: эмбрион на преимплантационной стадии развития» пишет, что, согласно последним данным ученых, новый, неповторимый, уникальный геном, ДНК которого управляет непрерывным развитием человека, начинается с оплодотворения, ни о каких до и после, недо- и префазах говорить недопустимо - это уже «эмбрион в преимплантационной фазе». Именно зачатие является чудом начала жизни, которое так бесцеремонно опошляется в свете тех или иных политических интересов. Каждый эмбриолог преклоняется перед чудом зарож- 
дения жизни, и любой учебник эмбриологии определяет зиготу как первую и главную стадию организма живого существа [Mercado 2015].

4. Эмбрион не является частью тела матери, которым она может распоряжаться по своему усмотрению. Другой тезис сторонников абортов о том, что эмбрион является частью тела матери, которым она вправе распоряжаться по своему усмотрению, также не выдерживает критики. Известный лозунг сторонников лозунга «мое тело - мое дело», который сегодня бередит умы молодежи и является чуть ли не главным аргументом сторонников абортов, опровергают генетики. Так, известный генетик, исследователь в области биоэтики, советник по правам ребенка доктор Мария дел Пилар Кальва Меркадо в своей публикации «Начало жизни: эмбрион на преимплантационной стадии развития» пишет, что «начиная с самого оплодотворения, зигота несет уникальный, отличный от матери и отца генетический материал, геном человека приводит к образованию тела человека, отличного от тела матери. Потому считаю, что к проявлениям “культуры смерти” и неуважительного отношения к жизни относятся аборт, экстренная контрацепция, все виды ЭКО, клонирование, использование эмбрионов, стволовых клеток эмбрионов. Даже конец жизни стал предметом экспериментов, сегодня мы являемся свидетелями эвтаназии и изъятия бьющихся сердец у пациентов с диагнозом «клиническая смерть мозга». Самые страшные сценарии относительно евгеники сбываются в наш век демократических “ценностей” и борьбы за “права человека"» [Mercado 2015].

5. Неспособность к выживанию вне утробы не является признаком отсутствия принадлежности к живому существу. Всемирно известный эмбриолог, доктор наук, заслуженный профессор клеточной биологии и анатомии Аризонского университета Уорд Кишер в своем докладе «Об окончательной деградации эмбриологии человека» поднимает проблему, связанную с тем, что с подачи узкого круга лиц в современную эмбриологию были введены псевдонаучные понятия, и сегодня происходит опасная «игра в слова» в дискуссиях по проблеме абортов и новых медицинских технологий. Он настаивает, что введение таких терминов, как «самостоятельное выживание», «содержательная жизнь», «достижение жизнеспособности», «индивидуация эмбриона», «оживление эмбриона», оправдывающие все те же теории о том, что тот, кто не способен жить вне тела матери, не способен выживать без технологической поддержки, т.е. до 24-27-й недели беременности, - это нежизнеспособный плод, неспособный к содержательной жизни. «Получается, что жизнь внутри материнской утробы, питаемая и защищенная, не является содержательной и жизнеспособной только потому, что она на данный момент не способна к жизни вне матки», недоумевает Уорд Кишер.

По мнению профессора кафедры эмбриологии МГУ В.А. Голиченкова, данный тезис не выдерживает критики ни с точки зрения науки, ни с точки зрения здравого смысла: «Внутриутробное развитие - это естественный процесс репродукции человека. Это с самого начала другой человек, и все млекопитающие проходят эмбриональную стадию своего развития. Неспособность к выживанию вне утробы на данной стадии развития не является признаком отсутствия принадлежности к живому существу, ведь и младенцы, и глубокие старики, и тяжело больные люди согласно этой логике не способны к самостоятельному выживанию. Но тогда, если ни зигота, ни эмбрион, ни плод не являются человеком, завтра мы скажем, что старики, инвалиды, тяжело больные, увечные это тоже не люди. Вряд ли кто-то скажет, что это - не люди» [Голиченков 2015].

6. Мы не имеем права решать, испытывает ли боль кто-то так же, как мы. Не стихают споры относительно того, способен ли эмбрион испытывать чувство боли. Сторонники абортов утверждают, что чувство боли, испытываемое 
эмбрионом, не может сравниться с болью, которую испытывает рожденный человек, следовательно, рассуждать о гуманности абортов бессмысленно. Этот тезис опровергается современными научными данными. Доктор наук, адъюнкт-профессор нейробиологии и анатомии университета штата Юта Маурен Кондик в своем докладе «Развитие фетального восприятия боли» приводит следующие факты: «Ощущение боли - это сложный комплекс реакций на внешний вредоносный или деструктивный раздражитель. Реакции нервной системы на боль любой интенсивности возникает к 8 неделям формирования эмбриона. И эмбрион реагирует на боль точно так же - он пробует от нее защититься. Спор вокруг внутриутробного восприятия боли идет не по вопросу, испытывает ли эмбрион боль, а испытывает ли он ее так же, как новорожденный или взрослый человек. Ранее считалось, и это закреплено в научных статьях, что для страдания от боли необходимо развитие связей в коре головного мозга. Современные исследования над пациентами с лиссэнцефалией (родившиеся без коры головного мозга), а также над животными с удаленной корой головного мозга опровергают данное положение: сознание сохраняется даже при отсутствии обширных частей головного мозга, при этом сохраняется разнообразное реагирование на боль. Сознательное восприятие боли локализуется в области таламуса, церебрально-таламические отделы формируются на 12-18-й неделях после зачатия. Множество исследований четко показало, что человеческий плод с 18-й недели демонстрирует гипофизарно-надпочечниковую, симпато-адреналиновую и сосудисто-стрессовую реакцию на физическое воздействие».

Ученые полагают, что «вопрос о фетальной боли - это не вопрос об отношении к фетальной боли, это вопрос о том, каким обществом мы хотим быть. Причинение боли любому существу - это бесчеловечно и жестоко. Мы не должны решать, испытывает ли боль кто-то так же, как мы, даже в отношении другого человека это сделать невозможно, но эмбрион отвечает на болевой раздражитель, значит испытывает боль начиная с 8-й недели своего развития. Люди в большинстве своем не одобряют жестокости. И вопрос не в том, есть ли у живого существа кора головного мозга, мы не одобряем отрывание плавников у рыб, лап у птиц, а ведь у этих живых существ тоже нет коры головного мозга. Так почему мы допускаем это в отношении человеческих эмбрионов, которые также заслуживают законодательной защиты от жестокости и причинения боли и вреда? ${ }^{1}$

7. Эмбрион ведет полноценную жкизнь, характерную для внутриутробной стадии развития человеческого существа. Относительно эмоциональной составляющей жизни человека до рождения интересно мнение доктора медицинских наук профессора междисциплинарного клинического центра Института интегративных исследований университета Хайфы (Израиль) Г.И. Брехмана. Его исследование «Эмоциональная жизнь ребенка до рождения» содержит следующие основные положения. Последние исследования подтверждают, что ребенок внутри утробы ведет полноценную эмоциональную жизнь, которая во многом зависит от эмоционального состояния матери и внешних воздействий. Конечно же первопроходцами стали сами матери, которые свидетельствовали, что ребенок эмоционально реагирует на слова, тембр голоса, звуки, мелодии, умеет радоваться или грустить, различает вкус [Брехман 2011].

8. Человек имеет право на безопасность и благоприятные условия развития в эмбриональный период. Самым главным является вывод, что внутриутробная фаза развития человека является одной из основных, что развитие человека

${ }^{1}$ Condic M.L. 2015. Congressional Testimony: Fetal Pain at 8 Weeks. URL: https://www.youtube.com/ watch? $v=0$ CTzJRF8v24 (accessed 30.04.2020). 
начинается с момента зачатия, и многие заболевания, например неврозы, также являются последствием внутриутробной фазы развития. Например, исследования показали, что дети, рожденные от матерей, которые во время беременности испытывали стресс или депрессию, менее адаптивны, нежели те, чьи матери провели беременность в здоровом эмоциональном фоне. Данное направление позволяет благоприятным образом усилить задатки и таланты ребенка, создать ребенку доброжелательную, психически физически активную атмосферу, чтобы он родился здоровым и полноценным» [Брехман 2011].

Таким образом, большинство ученых солидарны в следующих выводах:

- права человека до рождения должны быть защищены, прерывание жизни в утробе недопустимо;

- основной закон эмбриологии заключается в непрерывности жизни от зачатия до смерти;

- эмбриональное развитие является одной из стадий непрерывного развития человеческого существа;

- человеческая жизнь начинается с зиготы - слияния половых клеток отца и матери, ни о каких до и после, недо- и префазах жизни говорить недопустимо;

- эмбрион не является частью тела матери, генетически полностью отличается от организма матери и отца, следовательно, мать не может распоряжаться эмбрионом по своему усмотрению;

- неспособность к выживанию вне материнской утробы не может считаться признаком отсутствия принадлежности к живому существу;

- эмбрион ведет полноценную эмоциональную и физиологическую жизнь, характерную для внутриутробной стадии развития человеческого существа;

- эмбрион способен испытывать чувство боли, что подтверждается последними научными данными в области исследований фетальной боли;

- социальная и индивидуальная жизнь начинается до рождения, каждый человек имеет право на уважение еще до рождения, на безопасные пренатальные отношения, право на уважение и защиту непрерывности его опыта в течении беременности и до рождения ${ }^{1}$.

В заключение хотелось бы представить позицию одного из ведущих ученых, который наиболее ярко выразил позицию эмбриологии по исследуемому вопросу, профессора клеточной биологии и анатомии Аризонского университета Уорда Кишера. Он полагает, что долгом каждого эмбриолога как ученого является исправление вопиющих ошибок и заблуждений современности относительно познаний в области начальной стадии жизни человека и популяризация правды о внутриутробной стадии развития человека. По его глубокому убеждению, современное законодательство об абортах нарушает главный закон жизни - принцип непрерывности - от оплодотворения, рождения и до смерти, в которых мы наблюдаем совершенную последовательность событий, непрерывную от момента зарождения и до смерти. По его мнению, амбициозные заявления о допустимости абортов бесцеремонно принижают миссию ученых по всему миру. Эмбриология не должна быть заложницей социальных конструктов и политкорректным слугой той или иной политической системы, она основана на уважении жизни [Kischer 2008].

\section{Список литературы}

Брехман Г.И. 2011.Эмоциональная жизнь плода: от смутных догадок к науч-

\footnotetext{
1 Хартия о правах ребенка до, во время и после рождения. - Фундаментальные представления современной науки о начале человеческой жизни: материалы международного научного симпозиума. Москва, 7 июля 2015 г. С. 76-78.
} 
ным исследования. - Жіночий Лікар. № 2. С. 10-15. Доступ: http://brekhman. iri-as.org/stat/emozii_ploda.pdf (проверено 30.04.2020).

Голиченков В.А. 2015. Эмбрион не может заявить свои права, это можем сделать мы. - Фундаментальные представления современной науки о начале человеческой жизни: материалы международного научного симпозиума. Москва, 7 июля 2015 г. C. 14-19.

Kischer W.C. 2008. The Final Corruption of Human Embryology. - The Linacre Quarterly. Vol. 75. Is. 1. P. 31-39. February 2008. URL: https://www.researchgate.net/ publication/274531112_The_Final_Corruption_of_Human_Embryology (accessed 30.04.2020).

Mercado M. del P.C. 2015. Palabras como científico y médico genetista ante la SCJN. Bioética y pastoral de la vida. - Catholic.net. Доступ: https://es.catholic.net/op/ articulos/4027/cat/258/palabras-como-cientifico-y-medico-genetista-ante-la-scjn. html\#modal (проверено 30.04.2020).

RUDAKOVA Ekaterina Konstantinovna, Cand.Sci. (Pol.Sci.), Associate Professor of the Chair of International Relations and Political Science, Senior Researcher of Linguistic University of Nizhny Novgorod (3la Minina St, Nizhny Novgorod, Russia, 603155; kafedra_mo_nglu@mail.ru)

\section{INTERNATIONAL DISCUSSION ON THE PROBLEM OF HUMAN RIGHTS BEFORE BIRTH}

Abstract. The article presents the position of embryologists, biologists, and geneticists on the issue of legislative consolidation of human rights to life and dignity in the prenatal period. The article presents the latest data of fundamental science about the beginning of human life and the features of the intrauterine stage of human development. The author substantiates provisions that the embryo in the intrauterine developmental period has the fullness of human dignity from the moment of conception, and is not genetically the body or organ of the mother, so it needs a legal guarantee of safety and favorable conditions for physiological and mental development.

Keywords: demographic security, assisted reproductive technologies, in vitro fertilization, surrogacy, ethics, morality, human rights 